\title{
WHATSAPP AS A LEARNING TOOL DURING COVID -19 PANDEMIC: ADVANTAGES AND DISADVANTAGES
}

\author{
Sirajul Munir', Rita Erlinda², Hendra Eka Putra ${ }^{3}$, Hanif Afrinursalim ${ }^{4}$ \\ 1,2,3,4 Institut Agama Islam Negeri Batusangkar, Indonesia \\ Corresponding author: sirajulmunir@iainbatusangkar.ac.id
}

\begin{abstract}
Article Info
Abstract

Received: 22 September 2021

The purpose of the present study is to explore the advantages and

Accepted: 10 October 2021

Published: 26 October 2021 disadvantages of WhatsApp (WA) as a learning tool during Covid19 pandemic. WA is a messaging application that can be installed on smartphones and has many useful features. Researchers are

Keywords: WhatsApp; online learning; Covid-19 pandemics interested in researching since many students and lecturers choose WA as an application for continuous learning while one knows that many applications are actually intended for learning. The design of this research is a mix method (quantitative and qualitative). This research involved 168 respondents as a sample. The instrument of this research was an open-ended questionnaire. To analyze the questionnaire, the researchers used the data analysis based on Miles, Huberman, \& Saldana (2014). Three steps were applied: data condensation, data display, and drawing \& verifying conclusion. The study concludes that 73 percent of respondents believed that WA has more advantages than disadvantages. The advantages include it is effective and easy to use; the features are helpful, save internet quota, very light, easy to do communication, easy to observe the students. The disadvantages, however, is easy for the students to cheat, old chats are easily piled up by the new chats, the upload size is limited, and member capacity in the group is limited. These findings confirm that WA can be used as a learning tool with few limitations.
\end{abstract}

\section{INTRODUCTION}

It is undeniable that Covid-19 pandemic has changed all aspects in human's life starting from economic, social, politics, and even education. Until now, this virus is still spreading rapidly, which remains a mystery and research is still in progress. The impact of this virus also made a big change of education system in the world, including Indonesia. The government has determined to enforce online learning in all stages of education. Online learning is a modern learning which requires an internet connection and smartphone or PC to make the process of learning could happen. According to Abbad, Morris, \& de Nahlik (2009) online learning refers to the use of Information and Communication

\section{International Journal of Educational Best Practices (IJEBP)}


Technologies (ICT) to enable the students and lecturers have online interaction. This system is implemented to minimize the spreading of corona virus and to maximize the teaching and learning process. This system is applied in order to minimalize the mass spreading of Covid-19 virus and to maximize the teaching using technology. The lecturers and students need to adapt with online learning during the pandemic.

There are several smartphone applications which could be used by the lecturers and students in online learning. Some of those applications are Zoom, Google Classroom, Google Meet, and even WhatsApp. As everybody knows although WhatsApp doesn't have features that is intended to support online learning, several lecturers and students used it in doing online learning. WhatsApp is a social media application that functions to communicate, share messages, photos, files, and videos using the data network as a message delivery facility. According to Statista.com (2020) 87,7 percent of internet users in Indonesia use WhatsApp. Originally, WhatsApp is not an application that intended to help teaching and learning process. It is just an application which created to help online communication process. But during covid-19 pandemic, almost all of the teaching and learning process especially in Indonesia involved WhatsApp as media in doing online learning process. It allows users to provide instructions, deliver course materials, announcements, and comments in the form of live text, documents, images, audios, videos, links, and even installable application programs.

In the previous researches, there are some advantages which are found on the use of WhatsApp in online learning such as it is free of charge, simple to use, easy accessibility to learning material, easily available and down-loadable (Gon \& Rawekar, 2017). WhastApp is also effective because the students could access it anytime and anywhere (Hendro \& Eko, 2016). Amal (2019) also states that WhatsApp consumed less data package than others application which will be very helpful for the students in doing online learning. Dhahir (2020), furthermore, explains that WhatsApp feature that was able to combine media, as well as the availability of facilitators and constant learning anytime and anywhere, making it convenient for teaching and learning activities. WhatsApp is not a perfect application. There are also some disadvantages of WhatsApp which was found by the previous researcher like Got et al (2017) who state that some of the students don't have smartphone yet, message flooding, and no effort by some students when doing online learning. Gusuringa (2018) also adds that sometimes it can cause the user annoyed by the constant news and user must be able to access the internet to send and receive messages for free.

Prior research by Plana et al (2013) demonstrate that WhatsApp explicitly provide a learning and social benefits in the context of Higher Education. Similarly, Munir, Erlinda, \& Nursalim (2021) clearly conclude that most of the respondents believed that WhatsApp is very good application in online learning during Covid-19 pandemic. The researchers wanted to know what the advantages and disadvantages on the use of WA during Covid19 pandemic based on the students' opinion because as we know most of the students and the lecturers used WA as meda in doing online learning instead of other applications. This research is intended to know the advantages and disadvantages on the use of WhatsApp 
in online learning during Covid-19 pandemic especially in English Teaching Department classes in IAIN Batusangkar.

\section{Online learning}

Munir et al., (2021) postulate online learning as a teaching and learning system that utilizes electronic media specifically the utilization of internet in accessing materials; having interaction with contents, lecturers, and other students; and gaining assistance in learning process to get knowledge, make meaning, and progress through learning experience. Online learning is defined as learning carried out from a distance assisted by electronic devices, for instance, laptops, tablets, smartphones, and personal computers, which require an internet connection (Gonzalez \& Louis, 2018). It is also as stated by Nursalim (2021) that online learning is a teaching and learning system that utilizes electronic media specifically the utilization of internet in accessing materials; having interaction with contents, lecturers, and other students; and gaining assistance in learning process to gain knowledge, make meaning, and progress through learning experience. Moreover, Basar (2021) explains that online learning needs the availability of internet network. It could be concluded that online learning as a modern learning which require an internet connection and smartphone or PC to make the process of learning could happen.

\section{WhatsApp as a learning tool}

No one can deny the fact that the use of WhatsApp as a learning tool in Indonesia is increasingly popular in recent times. WhatsApp has various functions, such as text messages, attached images, audio files, video files, and links to web addresses (Cohavi, 2013). Church \& de Oliveira (2013) add that WhatsApp is a smartphone- and web-based instant message application that allows users to exchange information using a variety of media including text, image, video, and audio messages. It could be concluded that WhatsApp is a free social media application across multiple platforms iOS (formerly iPhone OS) and Android which has many features such as video call, voice note, voice call, group, attached files, etc. In the context of learning, WhatsApp gave opportunities to make a thoughtful learning (Bansal \& Joshi, 2014).

\section{Advantages and disadvantages of WhatsApp in online learning}

Hendro \& Eko (2016) attempt to identify several benefits of using the WhatsApp application, namely: (1) The exchange of information is faster and easier between lecturers and students; (2) interactions on social media encourages the emergence of new public spaces and new communication patterns between lecturers and students as producers of information itself; (3) changes in practices and communication spaces that were previously democratically managed; and (4) utilizing the WhatsApp application make students can study anywhere and anytime. Similarly, Gon \& Rawekar (2017) state other advantages of WhatsApp (1) Simple to use; (2) free of charge; (3) easily available 
and down-loadable; (4) easy accessibility to learning material; and (5) learning anytime anywhere.

The disadvantages, however, as Gusuringa (2018) explains: (1) It is only compatible with smartphones, many people do not have it yet; (2) Sometimes it is annoyed by the constant news; (3) One must be able to access the internet to send and receive messages for free; (4) In a group, only Group Admin can add people/ give admin titles to others in the group. Djamjuri and Kamilah (2020) also identify some disadvantages of WhatsApp in online learning (1) If the signal network is bad, it will hinder the process of sending teaching materials; (2) In video conference the meetings is very limited; (3) Sometimes the response is a bit slow when there are many incoming messages.

\section{METHODOLOGY}

The design of this research was a mixed method that combines quantitative and qualitative research. The population of this study was all students of English Teaching Department of IAIN Batusangkar who used WhatsApp as the application in online learning during covid-19 pandemics. All students who used WA as media in online learning during covid19 pandemics were involved to investigate their views on the advantages and disadvantages of using WhatsApp application. They include the second semester students, the fourth semester students, the sixth semester students, and the eighth semester students. The population was 270 students. In measuring the number of minimum samples in this study, the researchers used the Slovin formula. This formula was used to determine the number of samples from this population. To gain a sample that is truly representative of the population, the researchers also employed stratified random sampling to determine the minimum sample of each semester students. The total sample in this research was 168 students. The researchers obtained 37 second-semester students, 42 fourth-semester students, 41 sixth-semester students, and 48 eighth-semester students.

The instrument which the researchers used in this research was questionnaire. A questionnaire is an instrument in the form of questions or statements. The questionnaire consists of 21 items. After the research instrument was complete, the researchers asked three validators to validate the instrument by attaching an application letter willing to be a validator, validation sheet, table of specification of the instrument, and research instruments. The researchers focused on the language aspects of the instruments that the researchers have made. To be more convincing on the content validity of the instrument, the researchers used the Aiken's V formula to calculate the content-validity coefficient based on the results of evaluating by the validators for an item in terms of the extent of the items. The validity of this instrument in general after using Aiken's formula, was valid, whereas the validity of the instrument based on each aspect from three validators belongs to "High" category because it was > 0.80 and the validity product was automatically "Valid". In this research, the reliability test for each variable was calculated by looking at the level of Cronbach's alpha. Based on the result of the SPSS IBS Statistic 26, the researchers found that the level of Cronbach's Alpha at the questionnaire was

\section{International Journal of Educational Best Practices (IJEBP)}


0.63. It can be inferred that the instrument of this research was in the category of reliable because the result was $0.61<0.63<0.80$.

The questionnaire was distributed to explore students' opinions on the advantages and disadvantages of the use of WhatsApp application in English Teaching Department classes during the covid-19 pandemic. The questionnaire was constructed in the form of open-ended questionnaire. To collect the data of this research, the researchers used a questionnaire via Google Form and distribute it to the students were English Teaching Department students. To analyze the open-ended questionnaire, the researchers used the data analysis based on Miles et al., (2014). Three steps were employed: data condensation, data display, and drawing \& verifying conclusion.

\section{FINDINGS}

A. The Advantages of WhatsApp as media in doing online learning process during covid-19 pandemic.

Table 1. The number of students on advantages of WhatsApp as media in doing online learning process

\begin{tabular}{llc}
\hline No & \multicolumn{1}{c}{ Advantages } & Students \\
\hline 1 & Effective and easy to use & 47 \\
2 & The features are useful & 35 \\
3 & Save internet quota & 24 \\
4 & The application is very light & 9 \\
5 & Easy to do communication & 5 \\
6 & Make the lecturer easier to observe the students & 4 \\
\hline
\end{tabular}

Make the lecturer easier to observe the..

Easier to do communication

The application is very light

Save internet quota

The features are useful

Effective and easy to use

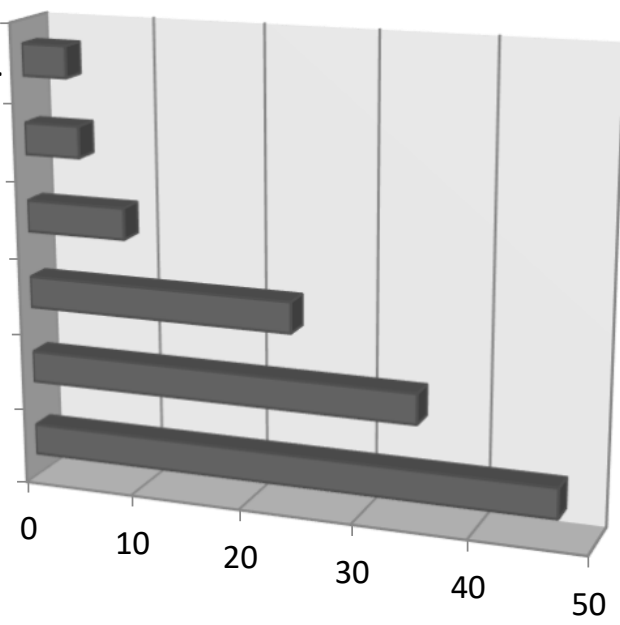

Histogram 1. The number of students on advantages of WhatsApp as media in doing online learning process 
Students who agreed that WA is a good media in online learning have several reasons which they commented through the questionnaire:

\section{Effective and easy to use}

47 respondents responded that WhatsApp is an effective media in online learning. It is because they could access it anytime and also the way of using WhatsApp is simple, so even if they never use it yet, they could understand how to use it immediately. They also responded that the application is easy to use compared with other applications.

The student named AAP stated that:

"During the COVID-19 pandemic, we must always keep our distance to stop the spread of the virus. Using WhatsApp as a learning media is the most effective way for now"

The similar response is also stated by IR:

"Yes, because WhatsApp is easy to use and we can quickly get information about lectures. WhatsApp is also good especially in the discussion because it helps us in lectures"

The student's name RW also conveyed the other reason:

"I think using WhatsApp is easier because using WhatsApp makes it easier for us both in uploading or downloading learning materials"

\section{The features of WhatsApp are helpful}

35 respondents agreed that using WhatsApp in the learning process would be helpful because of its features such as file sharing, group, video call, voice call, and voice note which are totally useful in learning process. Here are their comments.

"Yes, in general, both lecturers and students definitely use WhatsApp. In WhatsApp, there are video call, telephone, voice notes, and can send files in the form of mp3, mp4, pdf/doc/ppt/excel." (student's named AM)

Another student, named MHA also commented:

"It is because we are familiar with its features and it's easier to use"

Others (FZ, RF, MR) stated:

\section{International Journal of Educational Best Practices (IJEBP)}

Vol. 5 No. 2 October 2021

ISSN: 2581-0847

DOI: 10.32851/ijebp.v5n2.p168-182 
"Because we can use voice notes so we can understand the material more clearly".

\section{Save internet quota}

24 respondents state that using WhatsApp would save their internet quota compared to other applications. It is because the data consumed is small. Most of the students believed that it is very helpful because they would not spend much money to buy a data package. One of the students reported:

"During the COVID-19 pandemic, we must always keep our distance to stop the spread of the virus. Using WhatsApp as a learning medium is the most effective way for now because it doesn't require a lot of internet quota" (students name BRP).

Another student named FLJ, explained:

"Yes, it is easier to access and the data which we use is small and we can save our expense in buying quota"

Others (SD, HAN) stated:

"WhatsApp consumes much quota, and it makes it easier for us as students"

\section{The application is very light}

Nine respondents, in their reflection, reported that WhatsApp application is lighter than other applications. It means many kinds of the smartphones could install WhatsApp, not only high specs smartphones but also medium or even low spec smartphone could use WhatsApp. Here are the responses:

"Yes, it's good, because WhatsApp is a very light application" (student's named BS)

A similar comment is also stated by JP:

"WhatsApp is an application that is not too heavy compared to other applications"

The same response was explained by PM:

\section{International Journal of Educational Best Practices (IJEBP)}

Vol. 5 No. 2 October 2021

ISSN: 2581-0847

DOI: 10.32851/ijebp.v5n2.p168-182 
"It is because the WhatsApp application is easily accessible by students, it means that there are students who have certain constraints such as their cellphones that do not have high specifications, but at least the students must have or use WhatsApp."

\section{Easy to do communication}

Five respondents mentioned that WhatsApp makes communication easy. Some applications intended for online learning don't provide the space for the students and lecturers to have communication. As a result, WhatsApp can be a solution for them to solve the communication problem. The following comments were shown:

"WhatsApp application as a learning medium can make communication easier because you are already accustomed to using the application and its users are not too difficult, besides that there are also many users of this application." (AL)

ADP also supported it:

"It is easier to communicate even when the condition of the internet network is slightly disrupted compared to other applications"

AI stated a similar reason:

"Because it is quite fast to communicate with other lecturers and friends"

\section{Make the lecturers easy to observe the students}

Four respondents explained that WhatsApp application makes the lecturer easy to observe the students during online learning. It is because the lecturer could check the participation of the students in the group and also the lecturers could check whether the students already read the message or not. Here are the comments:

"Because when I used WhatsApp, it can be seen who is indeed present at the lesson or not, by looking at the message of who has seen it and there must be feedback from students so that the learning objectives are achieved." (AT)

Another student also commented:

\section{International Journal of Educational Best Practices (IJEBP)}

Vol. 5 No. 2 October 2021

ISSN: 2581-0847

DOI: 10.32851/ijebp.v5n2.p168-182 
"Lecturers can monitor their students. We can discuss with WA group, and we can also meet face-to-face using video call".

B. The Disadvantages of WhatsApp as media in doing online learning process during covid-19 pandemics.

Table 2. The number of students on disadvantages of WhatsApp as media in doing online learning process.

\begin{tabular}{clc}
\hline No & \multicolumn{1}{c}{ Advantages } & Students \\
\hline 1 & Make the students easy to do cheating & 30 \\
2 & Old chats are easily piled up by new chats & 6 \\
3 & The upload size of file is limited & 5 \\
4 & Member capacity in the group is limited & 3 \\
\hline
\end{tabular}

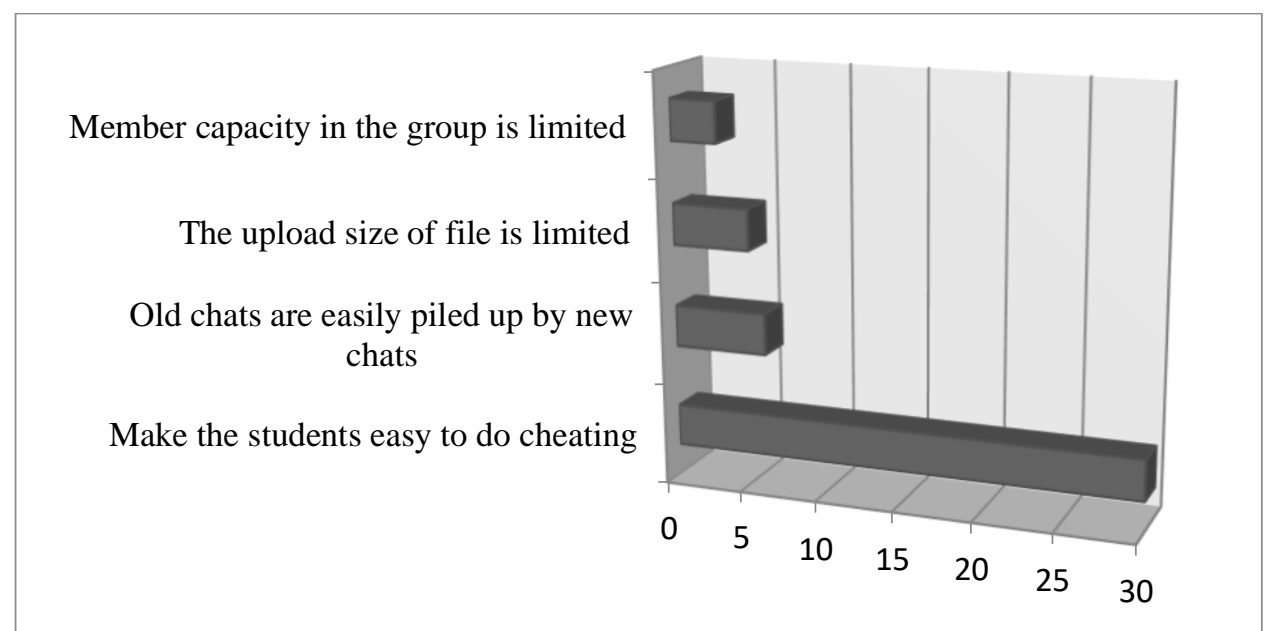

Histogram 2. The number of students on disadvantages of WhatsApp as media in doing online learning process

Students who disagreed stated several reasons why they disagreed that WhatsApp is not a good media in doing online learning process. Their reasons were:

\section{Make the students easy to do cheating.}

30 respondents claimed that WhatsApp is not a good media in the online learning process because it could give chance to the students to do cheating in learning. The lecturers could not see directly their students. As a result, the possibility to do cheating is high. These are the students' responses:

\section{International Journal of Educational Best Practices (IJEBP)}

Vol. 5 No. 2 October 2021

ISSN: 2581-0847

DOI: 10.32851/ijebp.v5n2.p168-182 
"No, in my opinion, it is less effective, because the explanation of the material obtained is not optimal, and also the lecturers do not know whether the students are really doing the lecture well." (DW)

FF also stated:

"Students are easy to cheat in making assignments and exams because there is no direct supervision from the lecturer"

DDU also mentioned similar reason:

"Less effective because there is a possibility of cheating".

\section{Old chats are easily piled up by new chats}

Six respondents believed that WhatsApp is not effective media in the online learning process because the old chats are easily piled up by new chats. The following are students' reflections as explained below:

"Because using WhatsApp sometimes chat likes to be buried so that the interaction between lecturers and students is not smooth and it might be a miscommunication" (SNP)

Another student, UA, stated that:

"It is because a lot of messages piled up"

Others also mentioned similar reasons:

"It is because sometimes when we ask the lecturers, the chat that we send can be piled up by other chats".

\section{The upload size of file is limited}

Five respondents gave negative statements. They explained that WhatsApp was not effective in online learning process because the upload size of file is limited. Here are the participants' statements:

"It is because it has limited file upload capacity. It makes us as the students sometimes confused how to send the assignment if our file size is big." (AWS)

A similar response is also explained by $\mathrm{RJ}$ :

\section{International Journal of Educational Best Practices (IJEBP)}

Vol. 5 No. 2 October 2021

ISSN: 2581-0847

DOI: 10.32851/ijebp.v5n2.p168-182 
"The capacity of files that can be uploaded using WhatsApp is small. As a result, it is not effective for students."

Parallel to this, DHJ also stated:

"No. Because sometimes I can't send videos that are large in size, so I have to use another application to upload videos and use WhatsApp just to send the link.

\section{Member capacity in the group is limited}

Three respondents claimed that WhatsApp is not an effective media in the online learning process because the member in the group is just limited to 250 people. The following comments are shown:

"The capacity of students in groups can sometimes be limited" (RM)

"WhatsApp limits the number of students in a group" (FJ).

\section{DISCUSSION}

This research found some advantages of the use of WhatsApp in online learning during Covid-19 pandemic. First, it is effective and easy to use. This idea is relevant to the research of Hendro \& Eko (2016) who state that WhatsApp is effective because the students could access it anytime and anywhere. Second, the features of WhatsApp are helpful. The previous study investigated by Burhoumi (2015) also concludes that WhatsApp can help students integrate videos, podcasts, messages, texts, images, and audio files. Furthermore, the research by La Hanisi, Risdiany, Dwi Utami, \& Sulisworo (2018) also clearly support this finding. They explain that WhatsApp has many collaborative features which will be very helpful in the teaching and learning process, especially in online learning. Third, save the internet quota. As it is widely accepted that in this pandemic, quota becomes one of the problems faced by the students in doing online learning. Most smartphone applications require them to consume a lot of quotas, and some students could effort themselves to buy quota because of economic problem.

WhatsApp is one of the applications which totally help them faced this problem because WhatsApp doesn't consume much quota instead it saves much quota compared to other applications. It is also supported by Djamdjuri \& Kamilah (2020) who highlighted WhatsApp is easy for lecturers or students to understand and does not take up a lot of quota data. Fourth, the application is very light. This finding is also in parallel with Amal's (2019)

\section{International Journal of Educational Best Practices (IJEBP)}

Vol. 5 No. 2 October 2021

ISSN: 2581-0847

DOI: 10.32851/ijebp.v5n2.p168-182 
work. He believes that installation data which consumed by WA is light and students don't need good specification smartphone to use it. Fifth, it is easy to do communication. Parallel to this, Hendro \& Eko (2016) confirmed that WhatsApp could make the exchange of information faster and easier between lecturers and students. Sixth, it makes the lecturers easy to observe the students. Students believed WhatsApp could help the lecturers observe their students in online learning. It is because the lecturers could check whether the students follow the learning process or not with the feature of WhatsApp.

This study does not only investigate the advantages. However, some disadvantages of WhatsApp in online learning during Covid-19 pandemic are also identified. First, it makes the students easy to cheat. For example, they can easily open many websites during exams, obtain other works without permission or citations, and copy correct answers. This finding is to support the previous study conducted by Watson \& Sottile (2010). It is also supported by Gon \& Rawekar (2017) that stated when using WhatsApp some students would have no efforts doing their assessment and some students share material just to impress facilitator without actually learning about it. Second, old chats are easily piled up by the new chats. Sometimes, chat likes to be buried so that the interaction between lecturers and students is not smooth and it might be a miscommunication. This is reasonable, as Gon et al (2017) state that some of the students have hard time in doing online learning using WhatsApp because sometimes the message flooding when the lecturers start the class. Third, the upload size is limited. It is reasonable, if user doesn't use document section, the upload size which could user used just only 100mb. Some of the respondents have a problem with this upload size. Fourth, member capacity in the group is limited. As everybody knows, the member limit of a group in WA is 256 members. Some of the respondents believe this number is not much enough for them. This finding confirms the previous statement by Adomi (2019) in his research that WhatsApp limits the member of a group up to 256 members.

\section{CONCLUSION}

Based on the findings and discussion of this research, it is concluded that WhatsApp has some advantages in the online learning during Covid-19 pandemic: effective and also easy to use, the features of WhatsApp are helpful, save internet quota, the application is very light, easier to do communication, and it make the lecturer easier to observe the students. WhatsApp, however, has the disadvantages: it makes the students easy to cheat, old chats are easily piled up by the new chats, the upload size is limited, and member capacity in the group is limited. This study implies that WhatsApp can be used as a learning tool in the classroom with few limitations.

\section{International Journal of Educational Best Practices (IJEBP)}

Vol. 5 No. 2 October 2021

ISSN: 2581-0847

DOI: 10.32851/ijebp.v5n2.p168-182 


\section{REFERENCES}

Abbad, M. M., Morris, D., \& de Nahlik, C. (2009). Looking under the Bonnet: Factors Affecting Student Adoption of E-Learning Systems in Jordan. The International Review of Research in Open and Distance Learning.

Adomi, E. (2019). Work related WhatsApp groups as knowledge sharing platforms among librarians in selected federal universities in Nigeria. Journal of ICT Development, Applications and Research., 1, 11-19.

Amal, K. B. (2019). Pembelajaran Blended Learning Melalui WhatsApp Group (WAG). Prosiding Seminar Nasional Fakultas Sosial Universitas Negeri Medan, 3, 700-702.

Bansal, T., \& Joshi, D. (2014). A Study of Students' Experiences of Mobile Learning. Global Journal of Human-Social Science Research, 5(6), 45-56. https://socialscienceresearch.org/index.php/GJHSS/article/view/1326

Basar, A. M. (2021). Problematika Pembelajaran Jarak Jauh Pada Masa Pandemi Covid-19. Edunesia: Jurnal Ilmiah Pendidikan, 2(1), 208-218. https://doi.org/10.51276/edu.v2i1.112

Burhoumi, C. (2015). The Effectiveness of WhatsApp Mobile Learning Activities Guided by Activity Theory on Students' Knowledge Management. Contemporary Educational Technology, 6(3), 221-238.

Church, K., \& de Oliveira, R. (2013). What's up with whatsapp?: comparing mobile instant messaging behaviors with traditional SMS. Proceedings of the 15th International Conference on Human-Computer Interaction with Mobile Devices and Services. New York: ACM., 252-361. https://doi.org/https://doi.org/10.1145/2493190.2493225

Cohavi, A. (2013). How did Whatsapp became the strongest social network? Calcalist.

Dhahir, D. F. (2020). The Usability of Whatsapp Messenger as Online Teaching-Learning Media. Journal of Information Technology and Its Utilization, 3(2), 48-52.

Djamdjuri, D. S., \& Kamilah, A. (2020). Whatsapp Media in Online Learning during Covid19 Pandemic. English Journal, 14(2), 69-74.

Gon, S., \& Rawekar, A. (2017). Effectivity of E-Learning through Whatsapp as a Teaching Learning Tool. MVP Journal of Medical Sciences, 4(19). https://doi.org/19. 10.18311/mvpjms/0/v0/i0/8454.

\section{International Journal of Educational Best Practices (IJEBP)}

Vol. 5 No. 2 October 2021

ISSN: 2581-0847

DOI: 10.32851/ijebp.v5n2.p168-182 
Gonzalez, D., \& Louis, R. St. (2018). Online Learning. J. I. Liontas (Ed.). The TESOL Encyclopedia of English Language Teaching (1st Ed.). https://doi.org/https://doi.org/10.1002/9781118784235.eelt0423

Gusuringa, N. I. B. (2018). The Contribution of Chat Using Whatsapp on The Student's Ability in Developing English Writing Sixth Semester of English Department at Uinsu. Thesis. Faculty of Tarbiyah Science and Lecturer Training. Department of English Education. State Islamic University of North Sumatra: Medan.

Hendro, E., \& Eko, P. M. (2016). The Effect og Using WhatsApp Messenger on Students Achievement in KKH class at PBIO FKIP UAD. Ahmad Dahlan University.

La Hanisi, A., Risdiany, R., Dwi Utami, Y., \& Sulisworo, D. (2018). The Use of WhatsApp in collaborative learning to improve English teaching and learning process. International Journal of Research Studies in Educational Technology, 7(1). https://doi.org/https://doi.org/10.5861/ijrset.2018.3004

Miles, M. B., Huberman, A. M., \& Saldana, J. (2014). Qualitative Data Analysis A Methods Sourcebook. Sage: London.

Munir, S., Erlinda, R., \& Nursalim, H. A. (2021). Students' Views on the Use of WhatsApp during Covid-19 Pandemic: A Study at IAIN Batusangkar. Indonesian Journal of English Language Teaching and Applied Linguistics, 5(2), 323-333. https://doi.org/http://dx.doi.org/10.21093/ijeltal.v5i2.740

Nursalim, H. A. (2021). Students' Opinion on The Use of WhatsApp Application in English Teaching Department Classes during Covid-19 Pandemics. Thesis. Faculty of Tarbiyah and Teaching Training. State Institute of Islamic Studies (IAIN) Batusangkar: Batusangkar.

Plana, M. G., Hopkins, J. E., Plana, M. G., \& Appel, C. (2013). Improving learners ' reading skills through instant short messages: a sample study using WhatsApp Global perspectives on Computer-Assisted Language Learning Improving learners ' reading skills through instant short messages : a sample study using WhatsAp. IV World CALL Conference, July, 10-13.

Statista.com. (2020). Penetration of Leading Social Networks in Indonesia as of Q3 2020. Retrieved from htttp://www.statista.com>statistics>Indonesia-social-net.

International Journal of Educational Best Practices (IJEBP)

Vol. 5 No. 2 October 2021

ISSN: 2581-0847

DOI: 10.32851/ijebp.v5n2.p168-182 
Watson, G., \& Sottile, J. (2010). Cheating in the Digital Age: Do Students Cheat More in Online Courses?. Online Journal of Distance Learning Administration, 13(1). 
